A Grave Case of Morphia and Cocaine Hubit [Considérations sur un cas grave de morphi-cocainomanie]. (Prog. Méd., May 1 2th, 1900.) Sollier, $P$.

The patient was a medical man, æt. 40 ; the morphia habit dated back ten years, the maximum daily dose being 3 grammes; the cocaine habit was more recent. When the case came under Sollier's treatment the intoxication was profound; the patient was emaciated; there was diffuse induration of the subcutaneous tissue, and there were numerous ulcers in the abdominal region where the patient injected the drugs; the urine contained albumen, and severe uræmic symptoms had appeared; the hæmoglobin was reduced to 4.5 per cent., and was shown by the spectroscope to be very imperfectly oxidised. The author specially indicates this blood-state, as he considers that the symptoms of collapse on the withdrawal of morphia are due to asphyxia.

The cocaine was stopped at once, and the morphia was rapidly reduced, being entirely suppressed by the sixth day. Sollier finds that this rapid method is quite free from danger, even in the worst cases, provided the desquamation of the intoxicated epithelial elements be vigorously promoted at the same time by purgatives, milk diet, diaphoretics, etc. Within two months the patient had almost returned to normal, except that the hæmoglobin was still a little below the standard.

W. C. Sullivan.

\title{
Physical Characters of Criminals [Caratteri di conformazione del delin- quenti]. (Istituzioni di Antropologia Criminale, Lecture I, Oct., 1900.) Zuccarelli.
}

This is the first of a series of lectures for popular audiences. The lectures appear under the title "Istituzioni di antropologia criminale" as a supplement to Prof. Zuccarelli's review "l'Anomalo."

The present lecture, which is prefaced by a letter from Prof. Benedikt, of Vienna, gives an outline of the views of the Italian school on the scope and value of criminal anthropology regarded as a distinct branch of science; and deals with the morphological peculiarities which that school attributes to the criminal.

The author emphasises the fact that stigmata of degeneracy are specially frequent in criminals, in idiots and imbeciles, and in the insane with hereditary taint. He has found from personal observations in the secondary schools of Naples that such stigmata are much more common in unruly pupils than in the well-conducted. W. C. Sullivan.

\section{Report of the Committee on Heredity. (Society for the Study of Inebriety,} April, r901.)

This is a report by a committee of the Society for the Study of Inebriety on the relation of heredity to intemperance. Besides the main report there are lengthy comments by several of the members, and a separate report by one member.

The main report, which is formulated in a series of numbered para- 